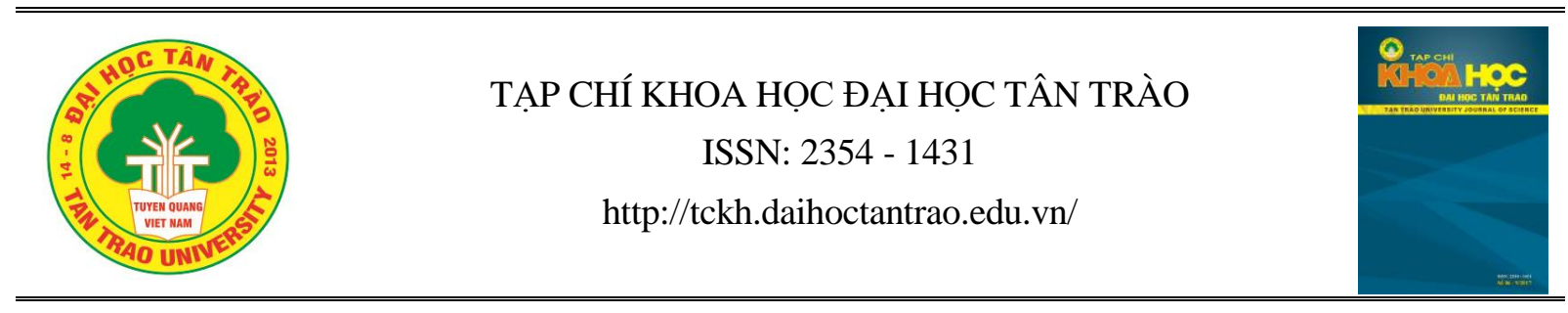

\title{
NGHIÊN CÚU QUY TRÌNH THUỶ PHÂN TỪNG PHẦN TRÚNG CẦU GAI ĐEN DIADEMA SETOSUM BĂNG ENZYME ALCALASE CÔNG NGHIỆP
}

\author{
Tạ Thị Luợng ${ }^{1,2}$, Igbonekwu-udoji Reagan Jonas ${ }^{l}$, Vi Đại Lâm ${ }^{l}$, Lưu Hồng Sơn ${ }^{l}$, Trịnh Thị Chung ${ }^{l}$, Nguyễn Thị Tình ${ }^{l}$, \\ Ngô Xuân Bình ${ }^{1}$, Đoàn Lan Phuoong ${ }^{3}$, Đinh Thị Kim Hoa ${ }^{1}$ \\ ${ }^{1}$ Truoòng Đại học Nông Lâm - Đại học Thái Nguyên \\ ${ }^{2}$ Đại hoc Queensland \\ ${ }^{3}$ Viện hóa học các hợp chất thiên nhiên
}

\section{Thông tin bài viết}

Ngày nhận bài:

2/5/2020

Ngày duyệt đăng:

$10 / 6 / 2020$

\section{Tù khóa:}

Cầu gai, nghiên cưu, thủy phân, dinh duõng, alcalase

\section{Tóm tắt}

Cầu gai là lớp có giá trị kinh tế cao thuộc động vật ngành Da gai ở Việt Nam còn ít được chú ý đến. Trứng Cầu gai đã được biết đến từ lâu trong y học dân tộc như là loại thực phẩm có giá trị dinh dưỡng và giá trị dược học cao. Việc thuỷ phân protein bằng enzyme thực sự là một phương pháp chế biến hiệu quả trong ngành công nghiệp thực phẩm nhằm nâng cao chất lượng dinh dưỡng của sản phẩm. Thuỷ phân có tác dụng phá vỡ các liên kết peptide để chuyển protein mạch dài thành những oligopeptide, peptide mạch ngắn và amino acid tự do tạo điều kiện cho cơ thể dễ hấp thụ. Nghiên cứu lựa chọn được các thông số cho quá trình thuỷ phân trứng Cầu gai đen Diadema setosum như sau: Nhiệt độ thuỷ phân $45-50^{\circ} \mathrm{C}$; tỉ lệ nguyên liệu/nước là 1/1; Tỉ lệ enzyme alcalase bổ sung là 1\%; Thời gian thuỷ phân là $7,5 \mathrm{~h}$.

\section{MỞ ĐẦU}

Cầu gai còn được gọi là nhum hay nhím biển ở Việt Nam, đây là nhóm động vật thuộc lớp Echinoidea, ngành Da gai Echiodermata. Hiện nay, có hơn 800 loài Cầu gai phân bố trên toàn thế giới, trong đó Cầu gai đen Diadema setosum phân bố ở nhiều vùng biển nông, nước cạn chủ yếu ở khu vực nhiệt đới Ấn Độ Dương đến Nhật Bản, Nam Thái Bình Dương và vùng biển Đỏ (Lesions et al., 2001). Ở Việt Nam, Cầu gai đen phân bố ở vùng ven biển miền Trung, vịnh $\mathrm{Bắc}$ Bộ, Trường Sa, Côn Đảo, và vùng biển phía Tây Nam Việt Nam (Hoàng Xuân Bền và Hứa Thái Tuyến, 2010; Latypov and Salin, 2011; Đỗ Thanh An và ctv., 2014; Hứa Thái
Nhân và ctv., 2019). Cầu gai là loài có giá trị kinh tế cao. Hiện tại, giá bán mỗi con Cầu gai đen tại các nhà hàng ở Phú Quốc là 40.000 - 45.000 đồng/con.

Các hợp chất sterol từ loài Cầu gai Diadema savignyi được chứng minh có hoạt tính gây độc tế bào trong khi các dẫn xuất steroit phân lập được từ loài sao biển Protoreaster nodosus thể hiện hoạt tính kháng viêm mạnh. Ngoài ra, các nghiên cứu đang được hoàn thiện về các loài Sao biển, Hải sâm và cầu gai khác cũng thu được nhiều kết quả rất khả quan, góp phần khẳng định giá trị dược liệu da gai của nước ta cũng như đưa các công bố khoa học về nghiên cứu sinh vật biển Việt Nam đến với cộng đồng khoa học quốc tế $[2,3]$. Năm 
2004, nhóm nghiên cứu của GS. Châu Văn Minh đã công bố sự phân lập và xác định cấu trúc của hai hợp chất steroit là 5,8-epiđioxicholest-6-en-3-ol và cholesterol cùng với glycerol 1-palmitat và glyxerol 1,3-đioleat-2-stearat từ cặn chiết metanol của loài cầu gai Diadema setosum thu thập tại Hạ Long, Việt Nam. Kết quả đánh giá hoạt tính gây độc tế bào cho thấy hợp chất này thể hiện hoạt tính gây độc tế bào mạnh trên 3 dòng tế bào ung thư người được thử nghiệm là $\mathrm{KB}$ (human epidermoid carcinoma - biểu mô), FL (fibrillary sarcoma of the uterus-màng tử cung) và Hep2 (Hepatocellular carcinoma - gan) với giá trị $\mathrm{IC}_{50}$ lần lượt là 2,0,3,93 và 2,4 $\mu \mathrm{g} / \mathrm{ml}$ [4]. Mới đây nhất, trong khuôn khổ đề án nghiên cứu trọng điểm tiềm năng về dược liệu biển vùng biển Đông Bắc Việt Nam giai đoạn 2013-2015, GS. Châu Văn Minh và cộng sự đã phân lập và xác định cấu trúc 08 hợp chất từ cặn chiết n-hexan hai loài cầu gai Strongylocentrotus intermedius và Diadema setosum [1]. Việc thuỷ phân protein bằng enzyme thực sự là một phương pháp chế biến hiệu quả trong ngành công nghiệp thực phẩm nhằm nâng cao chất lượng dinh dưỡng của sản phẩm.

Thuỷ phân có tác dụng phá vỡ các liên kết peptide để chuyển protein mạch dài thành những oligopeptide, peptide mạch ngắn và amino acid tự do tạo điều kiện cho cơ thể dễ hấp thụ. Như vậy, biện pháp dùng enzyme để thuỷ phân protein tạo ra các sản phẩm như axit amin, oligopeptit chính là một biện pháp công nghệ hữu hiệu. Do đó, nghiên cứu xây dựng quy trình thuỷ phân từng phần trứng Cầu gai đen Diadema sotesum để làm tiền đề cho các sản phẩm thực phẩm chức năng giàu protein phân tử lượng thấp, hướng tới phục vụ các đối tượng người khó hấp thụ dinh dưỡng là hướng đi đầy tiềm năng.

\section{PHƯƠNG PHÁP NGHIÊN CÚU}

\section{1. Đối tượng, vật liệu nghiên cứu}

Đối tượng nghiên cứu: Trứng cầu gai đen (Diadema setosum) tại vùng biển Nha Trang, Khánh Hòa. Mẫu được sơ chế và bảo quản ở $-18^{\circ} \mathrm{C}$, trước khi được chuyển đến phòng thí nghiệm.

\subsection{Bố trí thí nghiệm}

\subsubsection{Phân tích các chỉ tiêu hoá sinh của nguyên} liệu ban đầu

Tiến hành xác định các chỉ tiêu: Hàm lượng tro, độ ẩm, hàm lượng protein hòa tan tổng số, hàm lượng lipid tổng.

\subsubsection{Nghiên cứu lụa chọn nhiệt độ thuỷ phân}

Để xác định được nhiệt độ thủy phân phù hợp, tiến hành thủy phân $50 \mathrm{~g}$ trứng cầu gai với việc cố định tỷ lệ bổ sung nước $1 / 2$ và tỷ lệ bổ sung enzyme cố định $2 \%$ trong các khoảng nhiệt độ như sau: $40-45^{\circ} \mathrm{C}, 45-50^{\circ} \mathrm{C}$, $50-55^{\circ} \mathrm{C}, 55-60^{\circ} \mathrm{C}$. Trong quá trình thuỷ phân thực hiện thiết bị khuấy từ gia nhiệt. Sau $7 \mathrm{~h}$ tiến hành đo hàm lượng protein hoà tan tổng số nhằm chọn ra khoảng nhiệt độ thủy phân thích hợp nhất.

\begin{tabular}{|c|c|c|}
\hline $\begin{array}{c}\text { Công } \\
\text { thức }\end{array}$ & $\begin{array}{c}\text { Khoảng nhiệt } \\
\text { độ }\left({ }^{\circ} \mathrm{C}\right)\end{array}$ & $\begin{array}{c}\text { Hàm lượng } \\
\text { protein hoà tan } \\
\text { tổng số }(\mathbf{m g} / \mathbf{m l})\end{array}$ \\
\hline $\mathrm{CT} 1$ & $40-45^{\circ} \mathrm{C}$ & \\
\hline $\mathrm{CT} 2$ & $45-50^{\circ} \mathrm{C}$ & \\
\hline $\mathrm{CT} 3$ & $50-55^{\circ} \mathrm{C}$ & \\
\hline $\mathrm{CT} 4$ & $55-60^{\circ} \mathrm{C}$ & \\
\hline
\end{tabular}

\subsubsection{Nghiên cứu lụa chọn tỉ lệ nguyên liệu/nuớc}

Nước là môi trường để phân tán enzyme và cơ chất, là môi trường tăng cường quá trình phân cắt các liên kết nhị dương nên tỷ lệ nước có ảnh hưởng lớn đến tốc độ, chiều hướng và là một yếu tố điều chỉnh phản ứng thủy phân bởi enzyme. Trứng cầu gai $(50 \mathrm{~g})$ được xay nhỏ và bổ sung nước theo các tỷ lệ 1,0:0,5; 1,0:1,0;1,0:1,5; 1,0:2,0; 1,0:2,5 (w/v: g/ml). Bổ sung 2\% enzyme alcalase theo khối lượng nguyên liệu trứng Cầu gai. Tiến hành thủy phân ở điều kiện nhiệt độ lựa chọn được từ thí nghiệm 2 , sau $7 \mathrm{~h}$ tiến hành đo hàm lượng protein hòa tan tổng số nhằm chọn ra tỷ lệ nước bổ sung thích hợp nhất.

\begin{tabular}{|c|c|c|}
\hline $\begin{array}{c}\text { Công } \\
\text { thức }\end{array}$ & $\begin{array}{c}\text { Tỉ lệ nguyên } \\
\text { liệu/nước } \\
(\mathbf{w} / \mathbf{v})\end{array}$ & $\begin{array}{c}\text { Hàm lưọ̣ng } \\
\text { protein hoà tan } \\
\text { tổng số }(\mathbf{m g} / \mathbf{m l})\end{array}$ \\
\hline CT5 & $1,0: 0,5$ & \\
\hline CT6 & $1,0: 1,0$ & \\
\hline CT7 & $1,0: 1,5$ & \\
\hline CT8 & $1,0: 2,0$ & \\
\hline CT9 & $1,0: 2,5$ & \\
\hline
\end{tabular}

2.2.4. Nghiên cúu lụa chọn tỉ lệ enzyme alcalase

Trong điều kiện thừa cơ chất, nếu tăng nồng độ enzyme protease thì quá trình thuỷ phân xảy ra càng mãnh liệt. Khi nồng độ enzyme bão hoà với nồng độ cơ chất, dù tăng nồng độ enzyme bao nhiêu đi nữa vận tốc quá trình thuỷ phân rất ít thay đổi. Vì vậy, sau khi có kết quả nghiên cứu về tỷ lệ bổ sung nước tốt nhất, tiến 
hành nghiên cứu ảnh hưởng của tỷ lệ bổ sung enzyme đến quá trình thủy phân. Trứng cầu gai $(50 \mathrm{~g})$ được xay nhỏ, bổ sung nước theo tỷ lệ đã chọn ở thí nghiệm 3 , tỷ lệ bổ sung enzyme lần lượt như sau: $0,5 \%, 1,0 \%$, $1,5 \%, 2,0 \%, 2,5 \%(\mathrm{v} / \mathrm{w})$. Thủy phân ở điều kiện nhiệt độ thích hợp lựa chọn từ thí nghiệm 2, sau $7 \mathrm{~h}$ tiến hành đo hàm lượng protein hòa tan tổng số nhằm chọn ra tỷ lệ bổ sung enzyme thích hợp nhất.

\begin{tabular}{|c|c|c|}
\hline $\begin{array}{c}\text { Công } \\
\text { thức }\end{array}$ & $\begin{array}{c}\text { Tỉ lệ enzyme bổ } \\
\text { sung (v/w) }\end{array}$ & $\begin{array}{c}\text { Hàm lượng } \\
\text { protein hoà tan } \\
\text { tổng số (mg/ml) }\end{array}$ \\
\hline CT10 & 0,5 & \\
\hline CT11 & 1,0 & \\
\hline CT12 & 1,5 & \\
\hline CT13 & 2,0 & \\
\hline CT14 & 2,5 & \\
\hline
\end{tabular}

\subsubsection{Nghiên cúu lụa chọn thời gian thuỷ phân}

Thời gian thuỷ phân kéo dài hay rút ngắn đều ảnh hưởng lớn đến hiệu quả của quá trình thuỷ phân do enzyme tác động vào chất lượng của sản phẩm. Thời gian tác động kéo dài thì enzyme có điều kiện để cắt đứt mạch triệt để, dẫn đến sự biến đổi sâu sắc của cơ chất. Nhưng nếu kéo dài thời gian thuỷ phân quá mức sẽ tạo điều kiện cho vi sinh vật hoạt động làm sản sinh ra nhiều sản phẩm thứ cấp như: $\mathrm{NH}_{3}, \mathrm{H}_{2} \mathrm{~S}$, indol, scaptol..., đồng thời khi thời gian kéo dài hiệu quả kinh tế kém. Tuy nhiên, nếu rút ngắn thời gian thuỷ phân thì quá trình thuỷ phân diễn ra chưa triệt để dẫn tới hiệu suất thuỷ phân kém.

Tiến hành nghiên cứu ảnh hưởng của thời gian đến quá trình thủy phân, với thời gian như sau: $6,5 \mathrm{~h} ; 7,0 \mathrm{~h}$; $7,5 \mathrm{~h} ; 8,0 \mathrm{~h}$. Tiến hành thủy phân $50 \mathrm{~g}$ trứng cầu gai với các thông số về tỷ lệ bổ sung nước, tỷ lệ bổ sung enzyme, nhiệt độ đã được tối ưu ở các thí nghiệm trên, sau các mốc thời gian đã lựa chọn tiến hành phân tích xác định hàm lượng protein hòa tan tổng số của các mẫu.

\begin{tabular}{|c|c|c|}
\hline Công thức & $\begin{array}{c}\text { Thò̀i gian } \\
\text { thuỷ phân } \\
\text { (h) }\end{array}$ & $\begin{array}{c}\text { Hàm lượng } \\
\text { protein hoà tan } \\
\text { tổng số }(\mathbf{m g} / \mathbf{m l})\end{array}$ \\
\hline CT15 & 6,5 & \\
\hline CT16 & 7,0 & \\
\hline CT17 & 7,5 & \\
\hline CT18 & 8,0 & \\
\hline
\end{tabular}

2.3. Phương pháp phân tích hoá sinh
- Xác định độ ẩm theo phương pháp sấy ở nhiệt độ $100-105^{\circ} \mathrm{C}(\mathrm{TCVN} 3700$ - 90); Xác định hàm lượng tro toàn phần theo phương pháp nung mẫu ở 500$550^{\circ} \mathrm{C}$ (TCVN 5105-90);

- Xác định hàm lượng protein hòa tan tổng số theo phương pháp Lowry;

- Xác định hàm lượng lipit tổng theo phương pháp Bligh - Dyer.

\subsection{Phương pháp xử lý số liệu}

Các số liệu thu thập được thống kê ANOVA SPSS 20.

\section{KẾT QUẢ VÀ THẢO LUẦN}

3.1. Kết quả xác định thành phần cơ bản của nguyên liệu trứng Cầu gai đen

Tiến hành xác định một số thành phần hoá sinh của nguyên liệu trứng Cầu gai đen ban đầu để có được những biện pháp bảo quản và định hướng nghiên cứu phù hợp. Kết quả thể hiện ở bảng 3.1.

Bảng 3.1. Kết quả phân tích thành phàn của nguyên liệu trứng Cầu gai đen

\begin{tabular}{|c|c|c|}
\hline STT & Chỉ tiêu & Hàm lượng (\%) \\
\hline 1 & Protein & 68,98 ( mẫu khô) \\
\hline 2 & Lipid & 2,52 ( mẫu tươi) \\
\hline 3 & Tro & 0,98 ( mẫu tươi) \\
\hline 4 & Độ ẩm & 70,02 (mẫu tươi) \\
\hline 5 & Protein & 15,24 (mẫu tươi) \\
\hline
\end{tabular}

Từ kết quả nghiên cứu được trình bày trong bảng 3.1 ta thấy: Trứng Cầu gai có hàm lượng nước rất cao $(70,02 \%)$ và hàm lượng tro thấp điều này giải thích cho việc trứng Cầu gai rất dễ hư hỏng và khó bảo quả. Trứng Cầu gai có hàm lượng protein khá cao $(68,98 \%$ - phân tích với mẫu trứng Cầu gai khô có hàm lượng ẩm $12 \%$ ) và không thua kém gì thịt Hải sâm (cùng thuộc họ Da gai) [5]. Trong các loài cầu gai đen, cầu gai vàng và cầu gai trắng thì hàm lượng protein trong cầu gai đen là cao nhất [5]. Hàm lượng lipid trong trứng cầu gai $(2,52 \%)$ cao hơn đáng kể so với lượng lipid trong thịt hải sâm [5], điều này cho thấy trứng Cầu gai là loại thực phẩm giàu năng lượng.

3.2. Kết quả nghiên cứu lựa chọn nhiệt độ thuỷ phân trứng Cầu gai đen bằng enzyme alcalase

Bản chất của enzyme là protein nên kém bền với nhiệt, khi tăng hay giảm nhiệt độ thường ảnh hưởng tới hoạt tính của enzyme. Enzyme chỉ thể hiện hoạt tính cao nhất ở một giới hạn nhiệt độ nhất định. Với đa số enzyme, vùng nhiệt độ nằm trong khoảng nhiệt 
độ $40-50^{\circ} \mathrm{C}$, khi nhiệt độ lớn hơn $70^{\circ} \mathrm{C}$ đa số enzyme bị mất hoạt tính. Kết quả nghiên cứu lựa chọn nhiệt độ thuỷ phân trứng Cầu gai đen bằng enzyme alcalase được thể hiện ở bảng 3.2.

Bảng 3.2. Kết quả nghiên cưu lựa chọn nhiệt độ thuỷ phân trứng Cầu gai đen bằng enzyme alcalase

\begin{tabular}{|c|c|c|}
\hline $\begin{array}{c}\text { Công } \\
\text { thức }\end{array}$ & $\begin{array}{c}\text { Khoảng nhiệt độ } \\
\left({ }^{\circ} \mathbf{C}\right)\end{array}$ & $\begin{array}{c}\text { Hàm lượng } \\
\text { protein hoà tan } \\
\text { tổng số (mg/ml) }\end{array}$ \\
\hline $\mathrm{CT} 1$ & $40-45^{\circ} \mathrm{C}$ & $51,86^{\mathrm{a}}$ \\
\hline $\mathrm{CT} 2$ & $\mathbf{4 5 - 5 0 ^ { \circ } \mathrm { C }}$ & $\mathbf{6 8 , 0 4}^{\mathrm{a}}$ \\
\hline $\mathrm{CT} 3$ & $50-55^{\circ} \mathrm{C}$ & $59,57^{\mathrm{a}}$ \\
\hline $\mathrm{CT} 4$ & $55-60^{\circ} \mathrm{C}$ & $51,62^{\mathrm{c}}$ \\
\hline
\end{tabular}

Ghi chú: các chũ số trong cùng một cột biểu thị sư sai khác có ý nghĩa thống kê ở mức $\alpha=0,05$.

Từ kết quả bảng 3.2 ta thấy nhiệt độ ảnh hưởng rõ rệt đến quá trình thủy phân. Tiến hành thủy phân khối dịch ở các khoảng nhiệt độ khác nhau, thu được hàm lượng protein sau thủy phân là khác nhau. Thủy phân tại khoảng nhiệt độ $40-45^{\circ} \mathrm{C}$ hàm lượng protein thu được là thấp nhất $(51,86 \mathrm{mg} / \mathrm{ml})$. Khi tăng khoảng nhiệt độ thủy phân lên $45-50^{\circ} \mathrm{C}$, hàm lượng protein tăng một cách đáng kể (68,04 mg/ml). Tiếp tục tăng nhiệt độ thủy phân lên các khoảng nhiệt độ là $50-55^{\circ} \mathrm{C}, 55-60^{\circ} \mathrm{C}$ ta thấy hàm lượng protein lại giảm lần lượt xuống còn $59,57 \mathrm{mg} / \mathrm{ml}$ và $51,62 \mathrm{mg} / \mathrm{ml}$. Điều này có thể giải thích rằng ở khoảng nhiệt độ này đã vượt quá nhiệt độ tối ưu của enzyme, làm enzyme biến tính, vì vậy làm giảm hiệu suất thủy phân. Do đó, lựa chọn khoảng nhiệt độ $45-50{ }^{\circ} \mathrm{C}$ để thủy phân nguyên liệu bằng enzyme alcalase.

3.3. Kết quả nghiên cứu lựa chọn tỉ lệ nguyên liệu/nước cho quá trình thuỷ phân

Trứng cầu gai $(50 \mathrm{~g})$ được xay nhỏ và bổ sung nước theo các tỷ lệ $1,0: 0,5 ; 1,0: 1,0 ; 1,0: 1,5 ; 1,0: 2,0 ; 1,0: 2,5$ (w/v). Bổ sung $2 \%$ enzyme alcalase theo khối lượng tươi nguyên liệu, thủy phân ở điều kiện nhiệt độ 45 - 50 ${ }^{\circ} \mathrm{C}$, sau $7 \mathrm{~h}$ tiến hành đo hàm lượng protein hòa tan tổng số (phương pháp Lowry). Kết quả được trình bày trong bảng 3.3.

Bảng 3.3. Kết quả khảo sát ảnh hưởng của tỷ lẹ nuơóc bổ sung đến quá trình thủy phân trứng Cầu gai

(Diadema setosum) bằng enzyme alcalase

\begin{tabular}{|c|c|c|}
\hline $\begin{array}{c}\text { Công } \\
\text { thức }\end{array}$ & $\begin{array}{c}\text { Tỉ lệ nguyên } \\
\text { liệu/nước }\end{array}$ & $\begin{array}{c}\text { Hàm lượng } \\
\text { protein hoà tan } \\
\text { tổng số }(\mathbf{m g} / \mathrm{ml})\end{array}$ \\
\hline
\end{tabular}

\begin{tabular}{|l|l|l|}
\hline & $(\mathbf{w} / \mathbf{v})$ & \\
\hline CT5 & $1,0: 0,5$ & $53,24^{\mathrm{a}}$ \\
\hline CT6 & $\mathbf{1 , 0 : 1 , 0}$ & $\mathbf{6 8 , 7 9}^{\mathrm{b}}$ \\
\hline CT7 & $1,0: 1,5$ & $68,81^{\mathrm{b}}$ \\
\hline CT8 & $1,0: 2,0$ & $68,87^{\mathrm{b}}$ \\
\hline CT9 & $1,0: 2,5$ & $68,89^{\mathrm{b}}$ \\
\hline
\end{tabular}

Ghi chú: các chũ số trong cùng một cột biểu thị sụ sai khác có ý nghĩa thống kê ở mức $\alpha=0,05$.

Từ kết quả bảng 3.3 có thể thấy tỷ lệ nguyên liệu/nước (w/v) ảnh hưởng tới quá trình thủy phân. Kết quả khảo sát cho thấy ở tỷ lệ bổ sung là 1,0/0,5 thì hàm lượng protein tổng số thu được sau quá trình thủy phân là thấp nhất $(53,24 \mathrm{mg} / \mathrm{ml})$ do nguyên liệu chưa được tiếp xúc hết vào dung môi nước, enzyme thuỷ phân chưa liên kết được tối đa với các đại phân tử protetin của nguyên liệu. Khi tăng tỷ lệ bổ sung nước với tỷ lệ $1 / 1$ cho tỷ lệ protein là cao nhất $(68,79 \mathrm{mg} / \mathrm{ml})$ chứng tỏ với tỷ lệ này mẫu đã được hòa tan trong nước (với sự có mặt của enzyme alcalase $1,0 \%$ ). Khi tiếp tục tăng tỷ lệ bổ sung nước thì nhận thấy protein tổng số có tăng nhưng không đáng kể. Do đó để đảm bảo về yếu tố kinh tế và thuận tiện cho thí nghiệm lựa chọn công thức 6 , với tỷ lệ bổ sung nước/nguyên liệu 1/1 (w/v).

\subsection{Kết quả nghiên cứu lựa chọn tỉ lệ enzyme} alcalase bổ sung thích hợp

Trong điều kiện thừa cơ chất, nếu tăng nồng độ enzyme protease thì quá trình thuỷ phân xảy ra càng mãnh liệt. Khi nồng độ enzyme bão hoà với nồng độ cơ chất, dù tăng nồng độ enzyme bao nhiêu đi nữa vận tốc quá trình thuỷ phân rất ít thay đổi. Trứng cầu gai $(50 \mathrm{~g})$ được xay nhỏ, bổ sung nước theo tỷ lệ đã chọn ở nội dung 3, tỷ lệ bổ sung enzyme lần lượt như sau: $0,5 \%$, $1 \%, 1,5 \%, 2 \%, 2,5 \%$ (v/w). Thủy phân ở điều kiện nhiệt độ thích hợp lựa chọn từ nội dung 2 , sau $7 \mathrm{~h}$ tiến hành đo hàm lượng protein hòa tan tổng số nhằm chọn ra tỷ lệ bổ sung enzyme thích hợp nhất. Kết quả thể hiện ở bảng 3.4 .

Bảng 3.4. Kết quả nghiên cứu lựa chọn tỉ lệ enzyme alcalase bổ sung thich hợp

\begin{tabular}{|c|c|c|}
\hline $\begin{array}{c}\text { Công } \\
\text { thức }\end{array}$ & $\begin{array}{c}\text { Tỉ lệ enzyme bổ } \\
\text { sung (v/w) }\end{array}$ & $\begin{array}{c}\text { Hàm lượng } \\
\text { protein hoà tan } \\
\text { tổng số }(\mathbf{m g} / \mathbf{m l})\end{array}$ \\
\hline CT10 & 0,5 & $62,33^{\mathrm{a}}$ \\
\hline
\end{tabular}




\begin{tabular}{|c|c|c|}
\hline CT11 & $\mathbf{1}$ & $\mathbf{6 8 , 7 8}^{\text {b }}$ \\
\hline CT12 & 1,5 & $68,82^{\mathrm{b}}$ \\
\hline CT13 & 2 & $68,84^{\mathrm{b}}$ \\
\hline CT14 & 2,5 & $68,85^{\mathrm{b}}$ \\
\hline
\end{tabular}

Ghi chú: các chũ số trong cùng một cột biểu thị sụ sai khác có ý nghĩa thống kê ở múc $\alpha=0,05$.

Từ kết quả bảng 3.4 ta thấy tỷ lệ bổ sung enzyme ảnh hưởng tới quá trình thủy phân. Với tỷ lệ bổ sung enzyme là $0,5 \%$ hàm lượng protein tổng số thu được là thấp nhất $(62,33 \mathrm{mg} / \mathrm{ml})$, do với lượng enzyme này chưa đủ để thủy phân hết lượng mẫu. Khi tiếp tục tăng lượng enzyme lên $1 \%$ thì hàm lượng protein tổng số thu được tăng nhanh $(68,78 \mathrm{mg} / \mathrm{ml})$. Tiếp tục tăng emzyme bổ sung lên 1,5\%,2\%,2,5\% ta nhận thấy hàm lượng protein thu được so với tỷ lệ bổ sung $1 \%$ là tăng nhẹ nhưng không có sự khác biệt ở mức ý nghĩa $\alpha=0,05$. Điều này có thể giải thích do tỷ lệ enzyme là $1 \%$ đã đủ thủy phân hết lượng cơ chất. Do vậy, lựa chọn tỷ lệ bổ sung enzyme là $1 \%$ (so với trong lượng tươi nguyên liệu) cho thí nghiệm.

\subsection{Kết quả nghiên cứu lựa chọn thời gian thuỷ phân trứng Cầu gai đen bằng enzyme alcalase}

Thời gian thuỷ phân trứng Cầu gai kéo dài hay rút ngắn đều ảnh hưởng lớn đến hiệu quả của quá trình thuỷ phân do enzyme tác động vào chất lượng của sản phẩm. Thời gian tác động kéo dài thì enzyme có điều kiện để cắt đứt mạch triệt để, dẫn đến sự biến đổi sâu sắc của cơ chất. Nhưng nếu kéo dài thời gian thuỷ phân quá mức sẽ tạo điều kiện cho vi sinh vật hoạt động làm sản sinh ra nhiều sản phẩm thứ cấp như: $\mathrm{NH}_{3}, \mathrm{H}_{2} \mathrm{~S}$, indol, scaptol..., đồng thời khi thời gian kéo dài hiệu quả kinh tế kém. Tuy nhiên, nếu rút ngắn thời gian thuỷ phân thì quá trình thuỷ phân diễn ra chưa triệt để dẫn tới hiệu suất thuỷ phân kém. Tiến hành nghiên cứu ảnh hưởng của thời gian đến quá trình thủy phân, với thời gian nhu sau: 6,5h; 7h; 7,5h; 8h. Tiến hành thủy phân 50g trứng Cầu gai với các thông số về tỷ lệ bổ sung nước, tỷ lệ bổ sung enzyme, nhiệt độ đã được tối ưu ở các thí nghiệm trên, sau các mốc thời gian đã lựa chọn tiến hành phân tích xác định hàm lượng protein hòa tan tổng số của các mẫu. Kết quả thể hiện ở bảng 3.5 .

Bảng 3.5. Kết quả thí nghiệm xác định ảnh hwởng thời gian đến quá trình thủy phân

\begin{tabular}{|c|c|c|}
\hline $\begin{array}{c}\text { Công } \\
\text { thức }\end{array}$ & $\begin{array}{c}\text { Thời gian } \\
\text { thuỷ phân } \\
\text { (h) }\end{array}$ & $\begin{array}{c}\text { Hàm lượng } \\
\text { protein hoà tan } \\
\text { tổng số (mg/ml) }\end{array}$ \\
\hline CT15 & 6,5 & $60,74^{\mathrm{a}}$ \\
\hline CT16 & 7 & $66,23^{\mathrm{b}}$ \\
\hline CT17 & $\mathbf{7 , 5}$ & $\mathbf{6 8 , 5 8}^{\mathrm{c}}$ \\
\hline CT18 & 8 & $68,12^{\mathrm{b}}$ \\
\hline
\end{tabular}

Qua kết quả bảng 3.5 ta thấy thời gian thủy phân cũng ảnh hưởng tới hiệu suất thủy phân của khối dịch. Qua một số nghiên cứu trước đó chúng tôi quyết định tiến hành thủy phân tại các mốc thời gian lần lượt là 6,5h; $7 \mathrm{~h} ; 7,5 \mathrm{~h} ; 8 \mathrm{~h}$. Sau quá trình thủy phân khối dịch ở các mốc thời gian nói trên tiến hành đo hàm lượng protein các mẫu ta thấy: Hàm lượng protein thu được tại mốc thời gian thủy phân $6,5 \mathrm{~h}$ là thấp nhất $(60,74$ $\mathrm{mg} / \mathrm{ml})$. Khi tăng thời gian thủy phân lên $7 \mathrm{~h}$, nhận thấy hàm lượng protein tăng $(66,23 \mathrm{mg} / \mathrm{ml})$. Điều này chứng tỏ khi thủy phân ở $6,5 \mathrm{~h}$ dịch vẫn chưa được thủy phân hết. Tiếp tục tăng thời gian thời gian thủy phân lên 7,5h nhận thấy hàm lượng protein vẫn tăng $(68,58 \mathrm{mg} / \mathrm{ml})$. Tiếp tục tăng thời gian thủy phân lên $8 \mathrm{~h}$, hàm lượng protein lúc này giảm $(68,12 \mathrm{mg} / \mathrm{ml})$ và không có sự sai khác với công thức thủy phân ở 7,5h. Điều này có thể giải thích là do trong khoảng thời gian 7,5h lượng enzyme đã thủy phân triệt để lượng cơ chất. Từ kết quả thí nghiệm ta thấy tại thời gian thủy phân là $7,5 \mathrm{~h}$ thì khối dịch đã được thủy phân gần như hoàn toàn và cho hàm lượng protein là cao nhất. Do vậy, lựa chọn thời gian thủy phân là 7,5h.

\section{KẾT LUẬN}

Sử dụng phương pháp phân tích đơn yếu tố, thí nghiệm sau kế thừa kết quả nghiên cứu của thí nghiệm trước. Lựa chọn được các thông số cho quá trình thuỷ phân trứng Cầu Gai đen Diadema setosum như sau: Nhiệt độ thuỷ phân $45-50^{\circ} \mathrm{C}$; tỉ lệ nguyên liệu/nước là $1 / 1$; Tỉ lệ enzyme alcalase bổ sung là $1 \%$; Thời gian thuỷ phân là 7,5h. Trong quá trình thuỷ phân luôn thực hiện khuấy đảo và ổn định ở nhiệt độ lựa chọn. 


\section{TÀI LIỆU THAM KHẢO}

1. Châu Văn Minh, Đề án nghiên cứu trọng điểm Nghiên cúu tiềm năng về duợc liệu biển Vùng Đông 4 . Bắc Việt Nam, giai đoạn 2013 - 2015.

2. Châu Văn Minh, Nguyên Xuân Cường, Nguyễn Hải Đăng, Nguyễn Phương Thảo, Trần Hồng Quang, Nguyễn Hữu Tùng, Nguyễn Hoài Nam, Nguyễn Văn Hùng, PhamVăn Kiệm (2012), "Điểm lại các nghiên cưu hoá học và hoạt tính sinh học một số loài sinh vật biển Việt Nam trong giai đoạn 2006-2012”, Tạp chí Khoa học và Công nghệ.

3. Châu Văn Minh, Phan Văn Kiệm, Nguyễn Văn Hùng, Nguyễn Hoài Nam, Phạm Văn Cường
(2012), Dược liệu biển, thực trạng và co hội phát triển, NXB Khoa học tự nhiên và Công nghệ.

4. Đề tài nghiên cứu cấp Viện, Viện Khoa học và Công nghệ Việt Nam, Nghiên cứu tách chiết và sư dụng các hợp chất có hoạt tính sinh học tù nguồn động vật vật lớp da gai ở vùng biển Việt Nam 2003 - 2004.

5. Nguyễn Thị Vĩnh, Nguyễn Tài Lương, Đoàn Việt Bình và cộng sự, 1995: Tìm hiểu giá trị dinh duõng của ba loài Hải sâm (Holothuroidea) vùng biển Nha Trang và chế biến dịch chiết Hải sâm bằng kỹ thuật enzyme. Tạp chí Sinh học. 17 (2): 98-101.

\title{
Research on the hydrolysis of Diadema setosum seaurchin's egg by using industrial alcalase enzyme
}

Ta Thi Luong, Igbonekwu-udoji Reagan Jonas, Vi Dai Lam, Luu Hong Son, Trinh Thi Chung, Nguyen Thi Tinh, Ngo Xuan Binh, Doan Lan Phuong, Dinh Thi Kim Hoa

\begin{tabular}{l} 
Article info \\
\hline Recieved: \\
$2 / 5 / 2020$ \\
Accepted: \\
10/6/2020 \\
\hline
\end{tabular}

Keywords:

Echinoidia, research, hydrolysis, nutrition, alcalase

\begin{abstract}
The sea urchins are animals that can be found in a variety of saltwater habitats and have high economic values. Sea urchins belong to the class Echinoidea but they just have received a little attentions from researchers. The eggs of sea urchins have been known for a long time in traditional medicine because of both their nutrition and their pharmaceutical values. Using enzyme for hydrolysis process is a really effective method in food technology to improve the nutritional values of products. The enzymatic hydrolysis will help break peptide bonds to convert long-chain protein structure to oligopeptides, peptides and free amino acids that can be absorbed effectively by human. The research has found out the best parameters for the hydrolysis of Diadema setosum's egg in single-factor experimental design such as the temperature for the hydrolysis from $45^{\circ} \mathrm{C}$ to $50^{\circ} \mathrm{C}$; The ratio between egg and water is $1 / 1$; The ratio of alcalase enzyme is $1 \%$ compared with weigh of egg material and the time of the process is 7.5 hours.
\end{abstract}

